Sains Malaysiana 49(2)(2020): 439-445

http://dx.doi.org/10.17576/jsm-2020-4902-23

\title{
Identifying Light Pollution Sources at Two Major Observatories in Malaysia
}

(Pengenalpastian Sumber Pencemaran Cahaya di Balai Cerap Utama di Malaysia)

\author{
MOHAMmad R. TAHAR, NAZHATUlShima AHMAD* \& NUR H. ISMAIL
}

\begin{abstract}
A spectral observation and analysis were conducted in order to identify the main contributor of sky brightness at two of Malaysia's most active observatories. The light pollution observations were carried out under moonless clear night sky with a $90 \mathrm{~mm}$ refractor telescope and SBIG's Self Guiding Spectrograph. We found that the main contributor to Balai Cerap Teluk Kemang (BCTK) sky brightness is High Pressure Sodium (HPS) street lighting due to its number and density used within $5 \mathrm{~km}$ radius of the observatory. HPS spectral lines dominate the spectrum between $556-640 \mathrm{~nm}$, agrees with the orange hue visible to the naked eye. The intensity due to HPS lighting is so high that there was no trace of the concerned white LED spotlight less than $1 \mathrm{~km}$ away. However, some traces of elements from Mercury Vapor (MV) lamps at $3.6 \mathrm{~km}$ distance managed to reach the observatory in the green spectrum. The finding concludes that the nearby $L E D$ spotlight does not affect the night sky brightness over BCTK. Meanwhile, Langkawi National Observatory (LNO) sky profile was also observed during heavy fishing season as comparison. The sky spectra for LNO was similar to BCTK in the reds except for a very distinct peak in green region corresponding highly with green MV (532 - $547 \mathrm{~nm})$ with peaks at $536 \mathrm{~nm}$ and $546 \mathrm{~nm}$, matches the lamps used for squid fishing around the island. The intensity of the green MV light matches the intensity of HPS light sources, during the observation period of peak squid season in January. This made LNO a far less favorable condition for astronomical observing site compared to BCTK. We also found that LNO sky has brightened 3.767 times compared to finding of 2013.
\end{abstract}

Keywords: Light pollution; observatory; sky brightness; sky glow

\section{ABSTRAK}

Cerapan dan analisis spektrum telah dijalankan bagi mengenal pasti penyumbang utama kepada pencemaran cahaya di dua balai cerap paling aktif di Malaysia. Hasil kajian mendapati punca utama pencemaran langit di BCTK adalah daripada lampu jalan HPS (High Pressure Sodium). Ia berpunca daripada jumlah penggunaan terbanyak dan kepadatan yang tinggi dalam lingkungan jarak $5 \mathrm{~km}$. Garisan pancaran HPS mendominasi spektrum langit BCTK pada 556 - 640 $\mathrm{nm}$, selaras dengan warna jingga langit yang dilihat dengan mata kasar. Pancaran HPS amat kuat sehingga tiada langsung kesan spektrum daripada lampu sorot LED kurang dari $1 \mathrm{~km}$ dari BCTK. Walau bagaimanapun, garisan pancaran lampu wap raksa lebih kurang $3.6 \mathrm{~km}$ daripada BCTK dapat dilihat pada panjang gelombang $535.7 \mathrm{~nm}$. Kajian mendapati lampu LED di kawasan bersebelahan tidak memberi sebarang kesan kepada pencemaran langit BCTK. Sebagai perbandingan, spektrum langit Observatori Negara Langkawi (ONL) pada musim mencandat sotong juga digunakan dalam kajian ini. Spektrum cahaya langit ONL hampir menyerupai BCTK dalam cahaya merah, tetapi dengan tambahan garisan pancaran hijau yang amat jelas pada $536 \mathrm{~nm}$ dan $546 \mathrm{~nm}$, iaitu sepadan dengan lampu merkuri hijau yang digunakan oleh bot mencandat sotong sekitar Langkawi. Keamatan cahaya daripada lampu merkuri hijau menandingi keamatan lampu HPS pada waktu cerapan dibuat pada bulan Januari. Ini menunjukkan pada waktu tertentu, langit ONL adalah lebih tercemar berbanding langit di BCTK untuk pencerapan astronomi. Kajian ini juga mendapati peningkatan tahap kecerahan langit LNO yang meningkat 3.767 kali ganda berbanding cerapan yang dibuat pada tahun 2013.

Kata kunci: Balai cerap; kecerahan langit; pencemaran cahaya; spektrum

\section{INTRODUCTION}

Light pollution was first described way back in 1972 and already considered as a threat to astronomical research facilities, primarily optical observatories (Hoag 1972). Ever since then, the terms related to light pollution has grown to address all the different aspects of this subject such as, sky glow, light trespass, and sky illumination (Hänel et al. 2018). Light pollution is defined as change of night sky illumination above natural level mostly by artificial means (Falchi et al. 2011). The addiction of lighting up the night are always associated with security, wealth and modernity (Holker et al. 2010).

All the light that escapes upwards, either reflected by surfaces on the ground or intentionally directed to the sky interacts with the atmosphere and scatters (Rayleigh scattering) causing what is called sky glow where the sky appears illuminated (Duriscoe 2016; Kyba et al. 2011). This reduces the contrast of the night sky, making 
astronomy optical observations difficult (Lamphar \& Kocifaj 2016). That is why astronomers are amongst the early groups that are most concerned about this threat. They have been long monitoring the level of sky brightness photometrically at zenith where most of astronomical observations are conducted (Duriscoe 2016). This later progressed into all-sky mapping of sky brightness surrounding an area of interest and also development of simple device such as the handheld Sky Quality Meter (SQM) to measure sky brightness easily (Cinzano 2005).

Besides photometric measurements of the level of brightness of the sky, it is just as important to know the emission function (EF) to fully understand sky glow (Lamphar \& Kocifaj 2016). Since all types of artificial light sources have their own unique Spectral Power Distribution (SPD), it is possible to distinguish the various types of light sources that are responsible for night sky illumination at specific sites (Hänel et al. 2018).

For this study, two locations of interest were chosen due to their connection to astronomy, Balai Cerap Teluk Kemang (BCTK) and Langkawi National Observatory (LNO). The two observatories were chosen due to their active usage in research and education awareness in the country, especially LNO as the national observatory (Tahar et al. 2016). LNO is located on an island North of Peninsular Malaysia and started its operation in 2007. It is equipped with a $0.5 \mathrm{~m}$ Ritchey Chretien (RC) telescope in its stellar observatory and a few dedicated solar observing telescopes in its solar facility (Kamarudin 2019). The main objective of LNO is for observational astronomy research of the equatorial sky by any researcher.

Meanwhile BCTK is a more recent observatory established in 2012 by the state government. It is equipped with a slightly bigger RC telescope at $0.6 \mathrm{~m}$ for its stellar observatory (Tahar \& Ahmad 2019). It is also with almost similar setup as LNO for its solar observatory. The main difference between the two is BCTK is geared more towards education and awareness, equipped with a 82-room hotel just across their parking lot (Ibrahim et al. 2017). They both however share some similarities; both are located at touristic destinations for their respective state and are the most actively used observatories in Malaysia.

Measuring the sky brightness is therefore crucial for the observatories. Not only to know the sky limiting magnitude there, but also for historical reference of the sky condition above the observatories. This also can be used to gauge the change of sky illumination over the years. On top of that, it is also crucial to identify the sources of the sky glow so that a workable remedy can be planned to slowly alleviate the situation from getting worse.

\section{Measurement Site And Methods}

The method on how the research was conducted is described in the flowchart in Figure 1. It starts with investigating the areas surrounding both observatories for populated areas as this is one of the most proven relationship that affects sky brightness (Cinzano 2001;
Garstang 1986). Based on this finding, we define a perimeter radius that covers the nearby town. We then approached the local authorities to find the different types of outdoor lighting used and where they are located and later, we confirmed the type of light source by spectral observation. The sky glow spectra for the observatories were observe after that and compared to the light source spectra to find the light source that is causing light pollution for each facility.

\section{IDENTIFYING POSSIBLE SOURCES}

The first step taken was to look at the maps for both observatories and locate area with bright outdoor lightings ranging from streetlights to floodlights operated by local authorities. From the maps in Figure 2, we immediately found that for BCTK, the amount of populated area was reduced drastically after $5 \mathrm{~km}$ and is surrounded by plantations and forest for several tens of kilometers. Hence, a $5 \mathrm{~km}$ radius for external lighting survey was deemed sufficient. As for LNO, the $5 \mathrm{~km}$ radius barely reached higher populated areas as it is located in a forest reserve, so a $10 \mathrm{~km}$ radius was used. We also consider only the types of lighting that were used by the authorities and not including the area that privately owned, which had minimal contribution.

From interview with the relevant local authorities, we found that the Public Works Department (JKR) and the Electric Utility company (TNB) use only HPS lights with varying power to for all their streetlights. JKR uses more $250 \mathrm{~W}$ units with some $150 \mathrm{~W}$ at specific locations while TNB uses $150 \mathrm{~W}$ exclusively for all their streetlights. Only the local municipal councils had a variety of external lightings used other than HPS. Besides HPS, the local municipal also used Mercury Vapor (MV), Metal Halide $(\mathrm{MH})$ and white LED spotlight. This made it easier to locate, identify and select areas of interest for us to go collect spectral data for each of the type of lightings used by all the authorities.

A total of nine different types of streetlights were used in total between all of the local authorities. They are two types of HPS lights from JKR, one standard 150W HPS from TNB, two types of streetlights within BCTK compound itself and four different types of lights under the local municipal councils. These were the candidates used for light source spectra observation. The main concern of both observatories was the use of white colored LED, more significantly in BCTK. In BCTK, there are five poles of LED spotlights with each pole housing four units of $400 \mathrm{~W}$ lamp lighting up the beach just a few hundred meters away. The intensity and proximity of the installation was the biggest concern. MV streetlight were used on a $2.5 \mathrm{~km}$ stretch of road near the $5 \mathrm{~km}$ radius limit from BCTK.

LNO had a few stretches of road that started converting to white LEDs at the town of Kuah about $7 \mathrm{~km}$ from the observatory. It is less of a concern for LNO because of the distance. As for green MV light source, they were used by the municipal at BCTK to light up a small opening at the 
nearby beach but limited to three units only. At LNO, the green MV was used on a large scale for squid fishing that surrounds the entire island. The squid fishing vessels are of small types and fish near the coastline and their number can amount to more than 1,000 vessels on an average night.

\section{PHOTOMETRIC MEASUREMENT}

Photometric measurement of the sky brightness for both facilities were done with a portable Sky Quality MeterLens (SQM-L) that interprets the intensity in magnitude per $\operatorname{arcseconds}^{2}\left(\mathrm{mag} / \operatorname{arcsec}^{2}\right)$ in a 20-degree circular area (Cinzano 2007). This gives us a rough idea how severe the light pollution problem at each observatory and how much they differ in brightness. For consistency, this measurement was taken simultaneously as spectroscopic observation which will be elaborated next. The sky brightness final value is the average of ten readings to avoid any instrumental bias and varying conditions. Observations are also conducted under clear skies, similar to conditions for any astronomical observations (Hänel et al. 2018).

\section{SPECTROSCOPIC MEASUREMENT}

The spectroscopic observation was done using an SBIG setup which comprises of an ST-8XME CCD camera attached to Self-Guided Spectrograph (SGS). Using the lower resolution grating on the spectrograph, we managed to cover a wide spectrum range of $650 \mathrm{~nm}$ and simultaneously reduced exposure time for the sky glow spectral observation. The optics used for all the observation is a 90 $\mathrm{mm}$ refractor, convenient and portable for the project.

Light source observations are done with distance of roughly $100 \mathrm{~m}$ away from each streetlight, pointed directly to the lamp. As for the sky glow observations, the setup is pointed straight to the zenith. This corresponds to most methods of measuring sky brightness where zenith is the main concern because this is also where most astronomical observations are best carried out (Cinzano \& Falchi 2013). Exposures for sky glow observations are set at 30 min each and runs throughout the night.

\section{RESULTS}

\section{SKY BRIGHTNESS MEASUREMENT}

We found that the level of brightness for both sites were not far off with LNO being just a little darker than BCTK as measured in 2018. Photometric measurement of the sky brightness over both observatories are as in Table 1 . Interestingly, LNO sky brightness measurement taken in 2013 was recorded at $21.08 \mathrm{Mag} / \mathrm{arcsec}^{2}$ which is quite a significant drop in 5 years (Tahar \& Kamarudin 2014). The difference of $1.44 \mathrm{Mag} / \operatorname{arcsec}^{2}$ looks insignificant but it is rather significant when the difference in brightness is compared, with the astronomical apparent magnitude formula (Romanishin 2006):

$$
m_{1}-m_{2}=-2.5^{*} \log \frac{I_{1}}{I_{2}}
$$

This equals to 3.767 times increase in brightness over the span of 5 years which is a very significant increase.

\section{LIGHT SOURCE SPECTRA}

From the spectral observations of nine outdoor light source, we narrowed down the source to four different types based on their spectra profile. We however did not find MH source which the local municipal said was used at one of the sites, but it was instead of green MV type. They are 4 types of spectral observed, HPS (Figure 3), LED (Figure 4), MV (Figure 5) and green MV (Figure 6). All the graphs are limit to visible wavelength between $380-750 \mathrm{~nm}$ which also corresponds to optical observation window.

The HPS spectra covers quite a broad wavelength starting at $565 \mathrm{~nm}$ to $642 \mathrm{~nm}$ as can be seen in Figure 3 . There are four signature peaks at $568.6 \mathrm{~nm}(\mathrm{Na}), 584.7 \mathrm{~nm}$ $597.7 \mathrm{~nm}$ and $615.6 \mathrm{~nm}$, within that band. This covers mostly the yellow to red colors of the spectrum giving the familiar orange HPS color. There are also two faint green emission lines at $498.2 \mathrm{~nm}$ and $515.2 \mathrm{~nm}$ emitted.

This next light source spectra is of the biggest concern when we initiated this project, the white LED colored 5,500 $\mathrm{K} 400 \mathrm{~W}$ spotlight located at the beach next to BCTK. It covers almost all the colors in the visible wavelength from blue in $420 \mathrm{~nm}$ to red in $690 \mathrm{~nm}$, except for a dip at 480 $\mathrm{nm}$ as seen in Figure 4. This is a big concern as white LED emission is very broad and continuous. On a big scale, this would make astronomical observation useless over the entire visible spectrum, which is the main function of most observatory.

The spectral emission of MV lamps is quite distinct with very prominent peaks as in Figure 5. The longest wavelength emission at $589.5 \mathrm{~nm}$ is of yellow color. This results in a white colored light but appears blueish to the eye than the white LED. Green MV are also used in both locations but more widely in LNO. There were only three of the green MV spotlights used $1 \mathrm{~km}$ from BCTK while they number in the thousands on fishing vessels for LNO. This green MV emits only two lines at $535.7 \mathrm{~nm}(\mathrm{Hg})$ and $546 \mathrm{~nm}$ as in Figure 6.

\section{SKY GLOW SPECTRA}

After gathering the light spectra from the various light sources, we had some reference for what the sky glow observations would produce. Sky Glow observations were done under clear sky to get the results that is of similar condition to any astronomical observations. Some thin clouds were not a big problem as it would only intensify the readings but will not alter spectral response (Kyba et al. 2011). Each 30-min exposure were dark and bias calibrated and later median stacked to reduce noise. Due 
to the long exposure, another step to reduce cosmic noise was carried out with a spatial filter.

The sky glow spectra for BCTK is represented in Figure 7. From a simple observation, we can clearly see that the spectra clearly match that of HPS light emission. Further analysis of the emission lines confirms this as the four prominent lines at $568.6 \mathrm{~nm}, 584.7 \mathrm{~nm}, 597.7 \mathrm{~nm}$ and $615.6 \mathrm{~nm}$. There is also some influence from the MV lights from about $4 \mathrm{~km}$ away in the green, at $535.7 \mathrm{~nm}(\mathrm{Hg})$ and $546 \mathrm{~nm}(\mathrm{Hg})$, one third that of HPS in intensity. LED emission was nonexistent from the observations and this was unexpected.

It was expected to witness a similar result from LNO after the BCTK sky glow observation, but possibly with a lower intensity as it is surrounded by a forest reserve. In reference to Figure 7 , the LNO sky spectra is somewhat similar to that of BCTK with HPS emission very evident in the red spectrum. However, there is a stronger green emission from the green MV light source which are used by hundreds of squid fishing boats around the island of Langkawi during the month of January.
The two lines, $535.7 \mathrm{~nm}$ and $546 \mathrm{~nm}$ manage to match the intensity of HPS light making the sky of above LNO bright in green. The green MV emission grows in width over the wavelength as it increases in intensity. In BCTK, the $535.7(\mathrm{Hg})$ emission width is between $534 \mathrm{~nm}-536.5$ $\mathrm{nm}$, a $2.5 \mathrm{~nm}$ width. But at LNO, the window is broader, between $532.6 \mathrm{~nm}-542.6 \mathrm{~nm}$, a $10 \mathrm{~nm}$ width and exactly matches the green MV light source. The width for $546 \mathrm{~nm}$ emission is however the same for both locations.

Based on Rayleigh scattering equation which is inversely proportional to the fourth power of wavelength $\left(\lambda^{-4}\right)$, we know that shorter wavelength will scatter more, than longer wavelength radiation (Falchi et al. 2011). This effect leads to why the green light source caused much severe sky glow especially when observed from within the same area (Duriscoe et al. 2007) as in the case for LNO. Based on Rayleigh equation, the $535.7 \mathrm{~nm}(\mathrm{Hg})$ emission line from green MV lamp is 1.27 times more intense than that of HPS's $568.6 \mathrm{~nm}(\mathrm{Na})$ line. From the LNO sky glow spectra profile we can see that the green MV is able to match the intensity of HPS line with $27 \%$ smaller number of lamps.

TABLE 1. Sky brightness measured for BCTK \& LNO in 2013 \& 2018

\begin{tabular}{lcr}
\hline \multirow{2}{*}{ LOCATION / YEAR } & \multicolumn{2}{c}{ Sky brightness measured (mag/arcsec2) } \\
& 2018 & 2013 \\
BCTK & $19.33 \pm 0.025$ & - \\
LNO & $19.64 \pm 0.019$ & $21.08 \pm 0.015$ \\
\hline
\end{tabular}

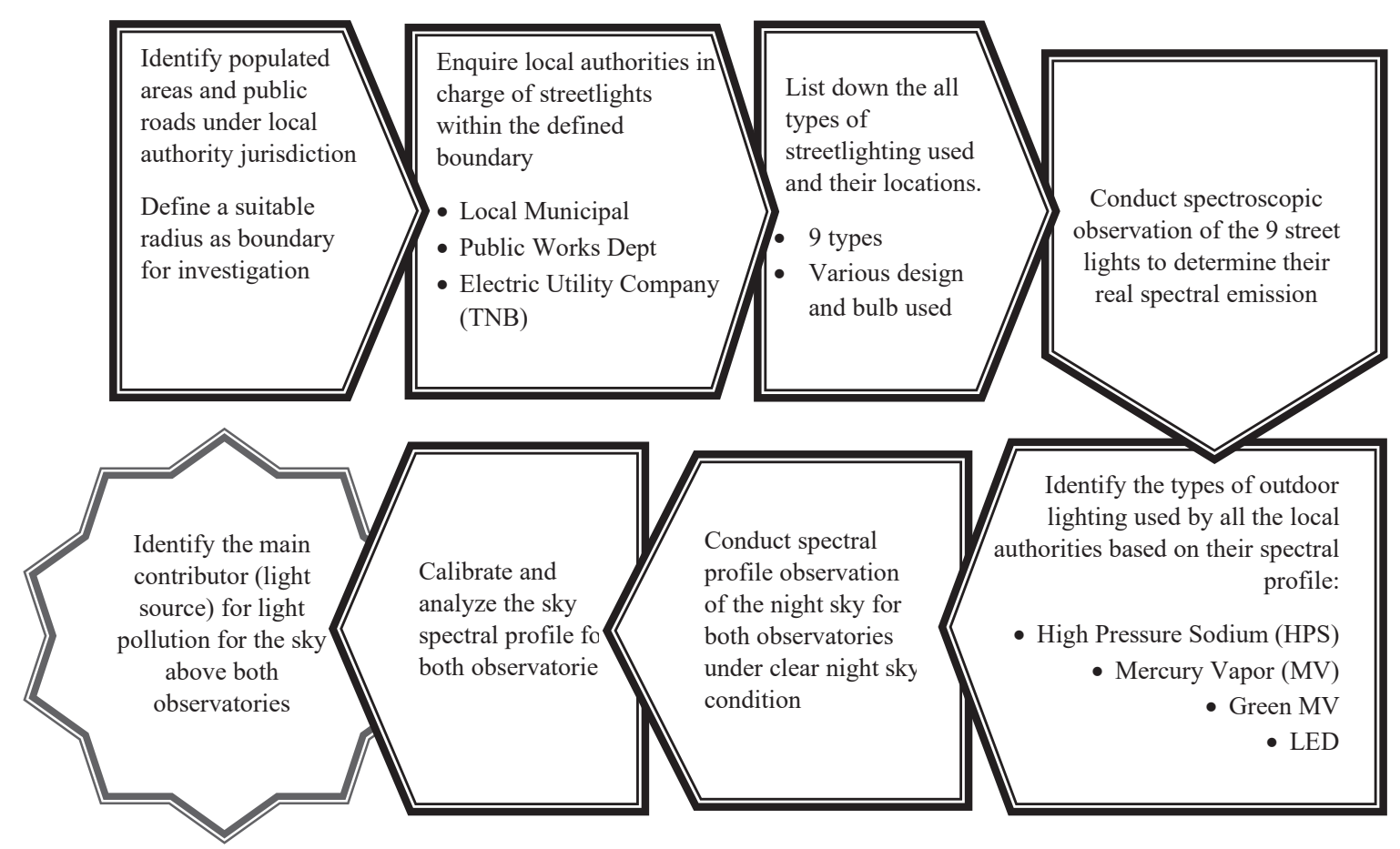

FIGURE 1. Flowchart of how the research was carried out to achieve the final objective 


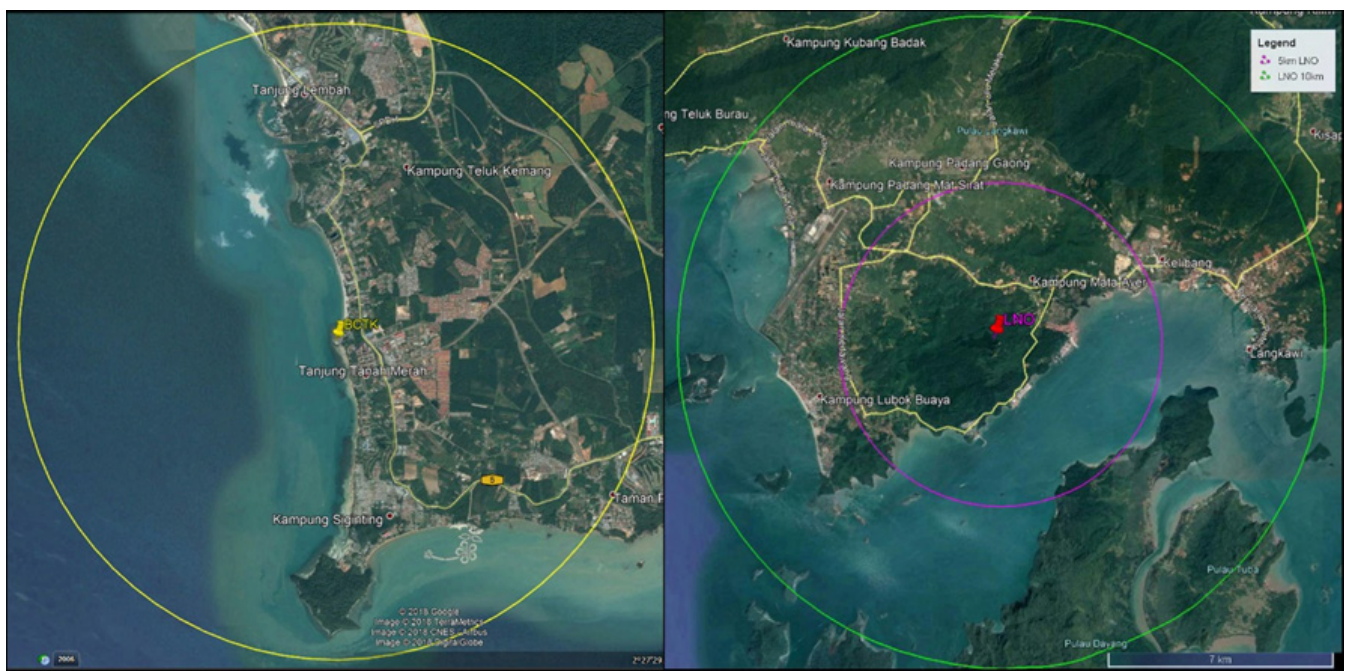

(a)

(b)

FIGURE 2. $5 \mathrm{~km}$ radius BCTK (a); $5 \mathrm{~km} \& 10 \mathrm{~km}$ radius for $\mathrm{LNO}$ (b)

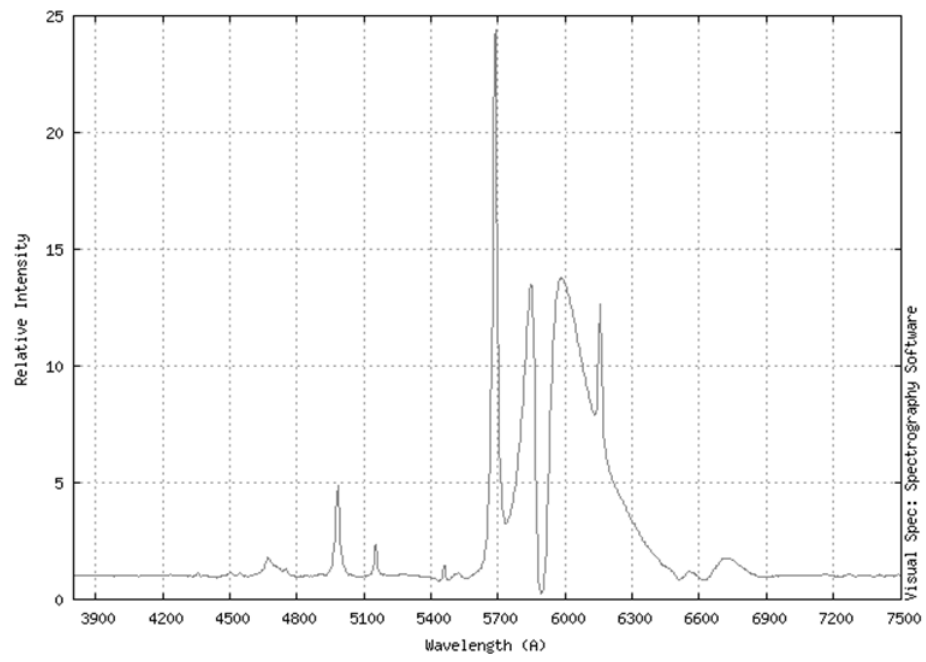

FIGURE 3. High Pressure Sodium (HPS) streetlight spectra produced the same results regardless of their different power rating and housing

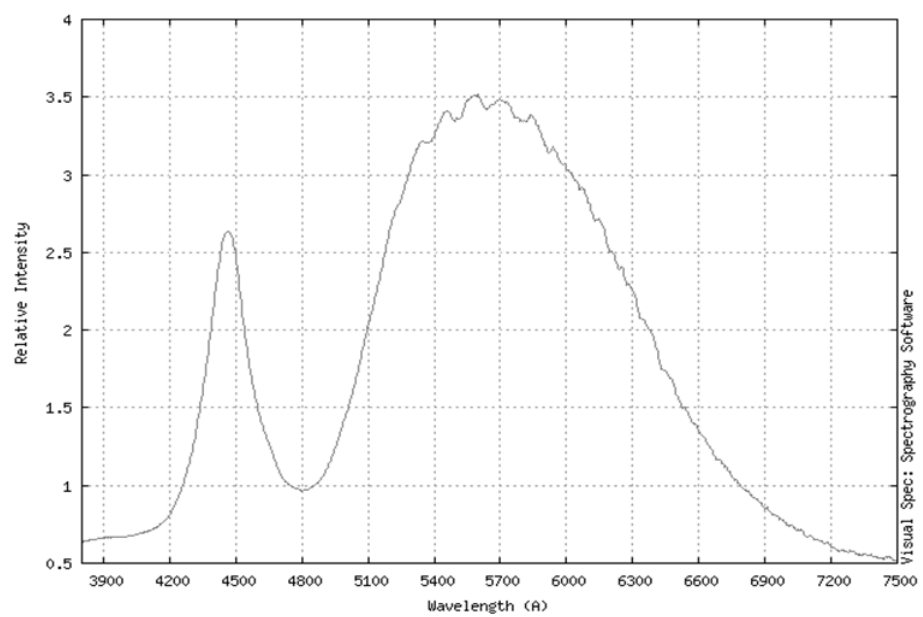

FIGURE 4. White colored 400W LED spotlight spectra. Specification provided by local municipal was 5,500K white LED 


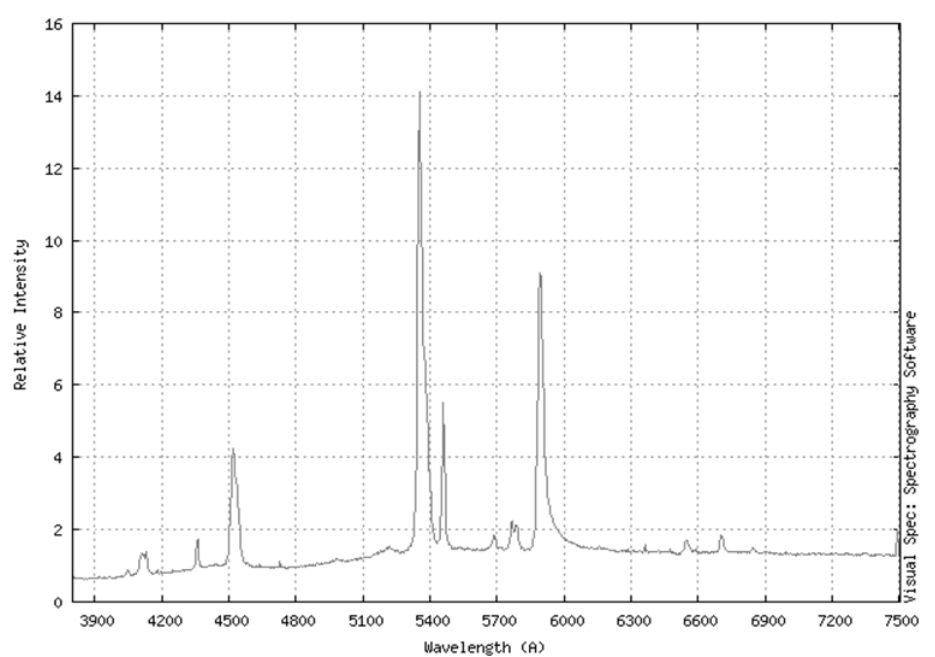

FIGURE 5. 250W Mercury Vapor (MV) light spectra. There was a total of 160 lamps near the $5 \mathrm{~km}$ radius from BCTK

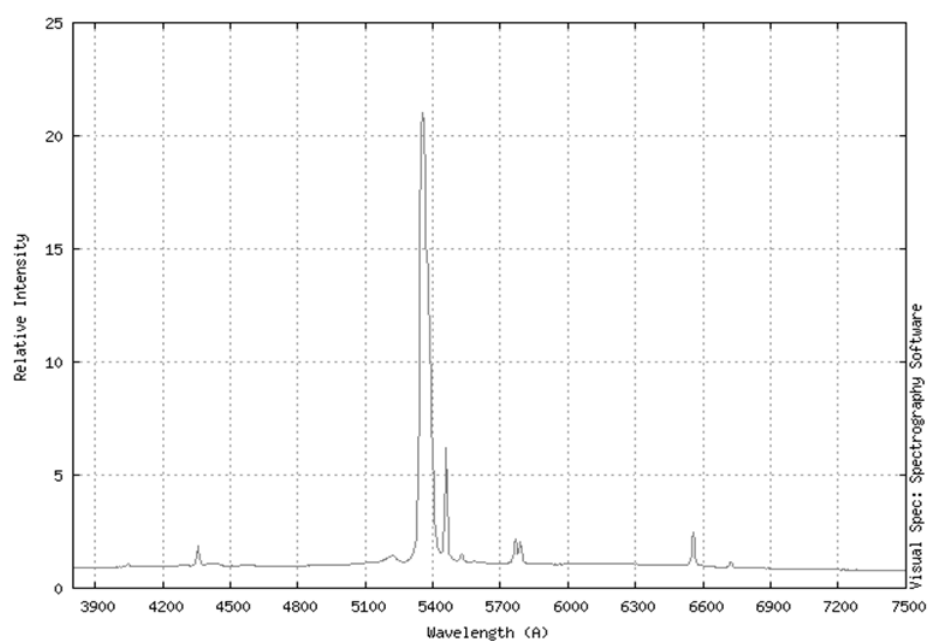

FIGURE 6. Green MV spectra. Used extensively for squid fishing around LNO

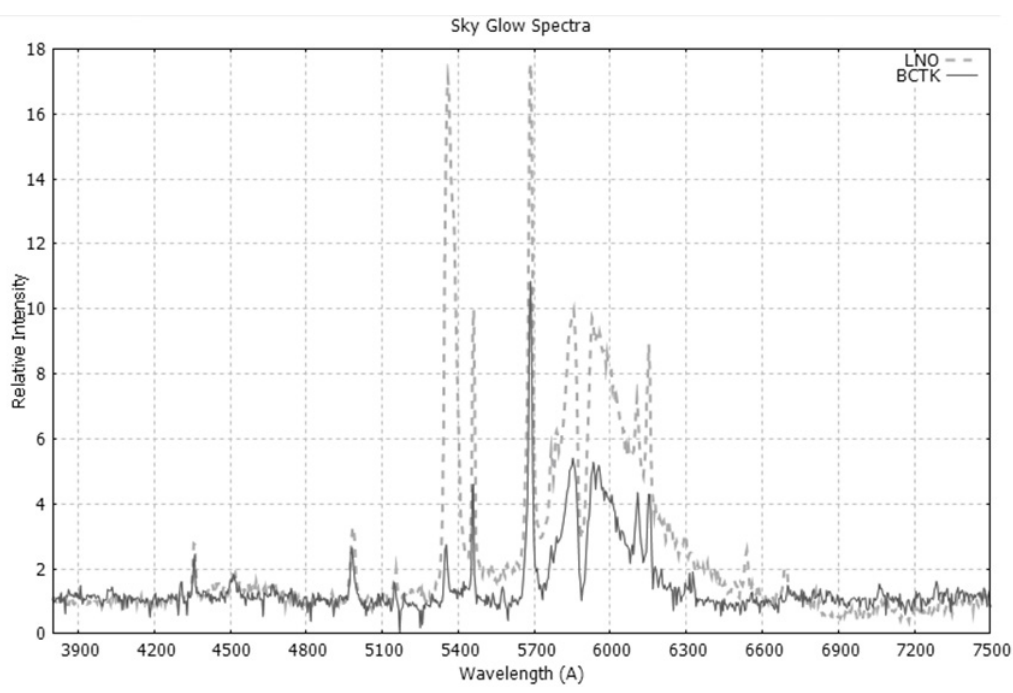

FIGURE 7. BCTK sky glow spectra shows a strong resemblance to HPS emission. While LNO sky glow spectra shows HPS clearly but with additional strong green emission from green MV squid fishing spotlights 


\section{CONCLUSION}

From the sky glow spectra for both observatories in Figure 7 , we can see the window for observations are clean in the lower end of the spectrum up to $532 \mathrm{~nm}$. HPS dominates the sky glow for both observatories from $566 \mathrm{~nm}$ to 640 $\mathrm{nm}$, which should result in slightly brighter sky brightness in the red spectrum. This is consistent with LNO sky brightness photometric measurement taken in 2016 (Chow \& Luo 2017) but without the squid fishing lights where it was a little brighter in red bandpass. During squid fishing seasons beginning in January observers should avoid 532 $\mathrm{nm}-547 \mathrm{~nm}$ spectral window or limit observations to bright object if affects from these light sources are to be reduced. Interestingly, LNO sky brightness also has increase from $21.08 \pm 0.015 \mathrm{mag} / \mathrm{arcsec}^{2}$ to $19.64 \pm 0.019 \mathrm{mag} / \mathrm{arcsec}^{2}$, a 1.44 magnitude difference which is 3.767 times brighter.

HPS had the most influence over both observatories' sky glow to due to the sheer number of HPS type used which makes up of more than $95 \%$ of external lightings. The low number of usages of white LED lights at both locations made its spectra non-visible in the observation. However, this does not mean it is safe to use around astronomical site as they cause pollution to the entire visible spectrum and stronger blue light pollution (Duriscoe et al. 2007).

\section{ACKNOWLEDGEMENTS}

This research was financially supported by the Ministry of Higher Education Malaysia (IIRG002B-19FNW). We thank the reviewers and associate editor for their comments which improved this manuscript.

\section{REFERENCES}

Chow, C.N. \& Luo, S.C. 2017. Limiting magnitudes and night sky brightness at the Langkawi National Observatory based on observations of standard stars. Journal of Physics: Conference Series JPCS. p. 852.

Cinzano, P. \& Falchi, F. 2013. Quantifying light pollution. Journal of Quantitative Spectroscopy and Radiative Transfer 139: 13-20.

Cinzano, P. \& Falchi, F. 2001. The first world atlas of the artificial night sky brightness. Monthly Notices of the Royal Astronomical Society 328(3): 689-707.

Cinzano, P. 2007. Report on Sky Quality Meter. ISTIL Internal Report 0.9: 1-5.

Cinzano, P. 2005. Night sky photometry with sky quality meter. ISTIL Internal Report 9: 1.4.

Duriscoe, D.M. 2016. Photometric indicators of visual night sky quality derived from all-sky brightness maps. Journal of Quantitative Spectroscopy and Radiative Transfer 181: 33-45.

Duriscoe, D.M., Luginbuhl, C.B. \& Moore, C.A. 2007. Measuring night-sky brightness with a wide-field CCD camera. Astronomical Society of the Pacific 119: 852.

Falchi, F., Cinzano, P., Elvidge, C.D., Keith, D.M. \& Haim, A. 2011. Limiting the impact of light pollution on human health, environment and stellar visibility. Journal of Environmental Management 92(10): 2714-2722.

Garstang, R.H. 1986. Model for artificial night-sky illumination. Astronomical Society of the Pacific 98(601): 364-375.
Hänel, A., Posch, T., Ribas, S.J., Aubée, M., Duriscoe, D., Jechow, A., Kollath, Z., Lolkemai, D.E., Moore, C., Schmidt, N., Spoelstra, H., Wuchterl, G. \& Kyba, C.C.M. 2018. Measuring night sky brightness: Methods and challenges. Journal of Quantitative Spectroscopy \& Radiative Transfer 205: 278-290.

Hoag, A.A. 1972. Observatories and city lights - One city fights light pollution. Mercury 1(5): 2.

Holker, F., Wolter, C., Perkin, E.K. \& Tockner, K. 2010. Light pollution as a biodiversity threat. Trends in Ecology \& Evolution 25(12): 681-682.

Ibrahim, I.A., Safiai, M.H., Jansari, E.A., Ahmad, D.Y., Mohd, A.H., Mohd, B. \& Hehsan, A. 2017. Observatories in Malaysia: Descendants of Islamic civilization superiority. International Journal of Civil Engineering and Technology 8: 782-795

Kamarudin, F. 2019. Ilmu Falak dan Masyarakat di Nusantara: Astronomi Islam, Astronomi Cerapan, Astronomi Komuniti dan Astronomi Kebudayaan. Volume 1. Tanjong Malim, Perak, Malaysia. Institut Tanah dan Ukur Negara (INSTUN). pp: 91-96.

Kyba, C.C.M., Ruhtz, T., Fischer, J.R. \& Ho"1ker, F. 2011. Cloud coverage acts as an amplifier for ecological light pollution in urban ecosystems. PLOS ONE 6(3): e17307.

Lamphar, S. \& Kocifaj, M. 2016. Urban artificial light emission function determined experimentally using night sky images. Journal of Quantitative Spectroscopy and Radiative Transfer 181: 87-95.

Romanishin, W. 2006. An Introduction to Astronomical Photometry using CCDs. Oklahoma: University of Oklahoma. Accessed from http://observatory.ou.edu.

Tahar, M.R. \& Ahmad, N. 2019. Ilmu Falak dan Masyarakat di Nusantara: Astronomi Islam, Astronomi Cerapan, Astronomi Komuniti dan Astronomi Kebudayaan. Volume 1. Tanjong Malim, Perak, Malaysia: Institut Tanah dan Ukur Negara (INSTUN). pp: 197-202.

Tahar, M.R. \& Kamarudin, F. 2014. Mapping Langkawi island sky brightness 2013. Paper presented at the International Conference on Space, Aeronautical and Navigational Electronics 2014, Ramada Hotel Melaka, Melaka, Malaysia.

Tahar, M.R., Kamarudin, F., Umar, R., Kamarudin, M.K.A., Sabri, H.S., Ahmad, K., Rahim, S.A. \& Baharim, M.S.A. 2017. Spatial model of sky brightness magnitude in Langkawi Island, Malaysia. Research in Astronomy \& Astrophysics 17(4): 037.

Mohammad R. Tahar, Nazhatulshima Ahmad* \& Nur H. Ismail Department of Physics

Faculty of Science

University of Malaya

50603 Kuala Lumpur, Federal Territory

Malaysia

Mohammad R. Tahar

National Space Agency

Pusat Angkasa Negara

42700 Banting, Selangor Darul Ehsan

Malaysia

*Corresponding author; email: n_ahmad@um.edu.my

Received: 19 August 2019

Accepted: 1 November 2019 
